\title{
A Place in the Sun?: The role of the Church in moral renewal and social transformation ${ }^{1}$
}

\author{
G A Duncan
}

(University of Pretoria)

\section{ABSTRACT}

\section{Christianity at the crossroads}

Mission Christianity exercised a destructive effect on traditional African cultures. In the post-1994 era, all religious faiths are encouraged to engage in the process of moral transformation. The Christian church is well-placed to play a continued constructive role in keeping with the prophetic and constructive role it played in the struggle against apartheid. This should be done through constructive engagement and critical solidarity, despite its internal divisions which may raise questions about its integrity. Christianity can no longer be treated either as a foreign faith or as a superior faith to others, including African Traditional Religion. Dialogue and hospitality are vital components in the process of moral renewal and social transformation.

As a young and naïve missionary in the late 1970s, I was challenged by a colleague, Rev Dr Ntsikelelo Katiya, concerning his strongly held view that missionaries had destroyed the traditional moral values of African peoples. He maintained that they had not been offered anything positive in return on which to base their ethical beliefs, decision-making and actions in response to life crises (cf. Dwane 1989:74). Despite personal differences at that time, a re-evaluation of Katiya's basic premise has led to a revised view where there is no longer any substantial disagreement.

It is true that missionaries, for the most part, did eliminate traditional value systems. It is also true that they replaced them with was the negative moral code of the Decalogue with its list of repetitive "Thou shalt nots ...'. This was compounded by a negative attitude to all things African and different. Keteyi (1998:20) said: 'The history of Christian missions ... may serve as an illustration of the pervasive way the mechanism of subjugating has ... penetrated our church life and religious life'. Goba (1988:3) would add that it happened in a way that was both 'paternalistic and racial'. The result of mission work was that 'Africans were give [sic] a basic Western education, taught Christian doctrine in

\footnotetext{
${ }^{1}$ This article is based on an address delivered at a conference at the University of Fort Hare in May 2001 on The Role and Function of Traditional Leadership and its Institutions: A Reflection on ethnic-cultural identity, African Religion and Customs for Moral Renewal and Social Transformation.
} 
combination with British cultural values, and encouraged to denounce "uncivilised" local customs ... that were fundamental to African social solidarity' (Odendaal 1984:5). This happened along with the denigration of the value systems of local communities whose values were characterised by respect for elders and ancestors, family values, sharing and hospitality, clear sexual codes, harmony and total well-being; in fact everything that contributed towards ubuntu in society. What is particularly significant is that these values are in no way opposed to the core values of Christianity, including the oneness of God, God's attributes - omniscience, omnipresence and omnipotence, the possibility of experiencing an authentic relationship with a supreme transcendent being and the presence of God as Spirit (Seoka 1997:7-8). Nevertheless it was assumed that they were less appropriate than these same values expressed in negative and prohibitive Victorian terms and were 'exploited and deliberately misconstrued so as to promote Western religious practice' (:5). But what Christian could object to the sentiments expressed by Mulago (1991:120,121): 'for black Africans living means existing in the bosom of the community; it means participating in the sacred life - and all life is sacred - of the ancestors' in view of our own veneration of our forbears and even in view of our affirmation of the 'communion of saints'? The same question might be raised concerning our commemoration of All Saints' Day and All Souls' Day in the Christian Calendar? $^{2}$ From this we can see that historically the church has played an important role in the development of the nation, though the value of its contribution might well be questioned.

In the period since 1994, religion in general, and the church in particular, has had a significant role to play in our new multi-faith society. This is despite Christianity having been relegated to a place in common with other religious faiths which would interpret this as an elevation of their own status. We live in a secularised state where religious communities are encouraged to play an active role in the formation of public policy. After all, they 'have a constitutionally recognised sphere of autonomy, but who collaborate with the state in tasks of mutual concern .... Religious leaders are obliged to maintain their historic role of being the moral conscience of society and raise their voices of protests against ...violations of human dignity' (Omar 1999:27). This is so at the behest of the State President and senior government ministers who continually call upon faith communities to initiate and

\footnotetext{
${ }^{2}$ I never cease to be amazed by the irrational fervour with many white people denounce ancestor veneration in light of our own tendencies to visit and maintain the graves of our ancestors, to talk to or with them, to seek solace and even expect some kind of guidance from them.
} 
promote programmes of moral renewal. This constitutes a tacit recognition that the state cannot achieve moral regeneration on its own. It is also a statement that never again can one faith community be allowed to gain ascendancy and exercise such heretical power for evil as we saw in the pre-1994 regime where a symbiotic relationship existed between one group of churches (Dutch Reformed) and the government with the result that each fed off the other in a parasitic manner. In addition to this certain African Initiated Churches, notably the Zion Christian Church (ZCC), gave an apparent veneer of legitimacy to apartheid (as when it invited former State President PW Botha to give an address to its gathered assembly at Moriah, Easter 1985). Also, English-speaking churches, and many individual members, also colluded to maintain apartheid despite their frequent public statements to the contrary: 'In practice ...many English-speaking Church people are also guilty of racism' (Bax 1983:112-143; cf. Villa-Vicencio 1988). Consequently, the Christian Church in South Africa has an outstanding record in legitimising the state though its role has been at times both ambivalent and ambiguous.

It is also true says Mkhatshwa (1999:67) that '[d]uring the struggle for liberation the churches impacted on public leaders and public life'. In this the Christian Church was not alone among the faith communities. Omar (1999:27) observed that the Church represented a 'strong influence on anti-Apartheid culture'. It achieved this by being both vocal and effective. Consequently, it played a prophetic and constructive role in the demise of apartheid. There were churches, notably the United Congregational Church of Southern Africa (UCCSA) (Van der Water \& De Gruchy 1999:231-253), and many members of these churches who stood out and challenged the very legitimacy of institutionalised oppression. The ambiguity of the responses of the English-speaking churches over many years has been ably demonstrated by Cochrane (1987) and Villa-Vicencio (1988). This should not surprise us since they were 'essentially social respondents to the dominant order' (VillaVicencio 1988:223). The danger is that they remain so today.

However, since 1994, the same churches have suffered from 'confusion, uncertainty and narrow denominationalism' according to Mkhatshwa (1999:67). The church has lost its bearings in a postapartheid dispensation, having abandoned its ecumenical approach from which it derived its strength to withstand the total onslaught of a totalitarian government. A significant example of this was the closure of the Federal Theological Seminary of Southern Africa in 1994. Added to which is the apparent jockeying of certain church leaders always to be the first to pronounce on an issue. Even when doing this on behalf of their 
own denomination, there is a clear perception that they are speaking on behalf of all South African Christians as a result of the media coverage they attract. This happens despite the fact that there exists an ecumenical instrument to do this ie. the South African Council of Churches (SACC). Even the SACC is guilty at times of making pronouncements ignoring the due process of consultation with members. However, this might be challenged on the basis of what is the point of having an ecumenical instrument if it constantly has to refer back to its constituent members before it speaks out on any matter? Since the churches cannot even work together it is perhaps expecting too much to expect them to work constructively with other faith communities. This raises the question whether or not the church as an institution has the capacity presently to contribute to current debates on moral regeneration focussing particularly on crime, poverty, the HIV/AIDS pandemic and corruption in South African society.

What is required as a matter of urgency is for the church to rouse itself from the state of occasionally 'talking in its sleep' (Trevor Huddleston's analogy in Walshe 1995:46). For the church to be an authentic contributor to the moral and social regeneration of South Africa it will have to adopt a prophetic stance of critical solidarity of word and action. This will challenge the attitude of obsequious uncritical solidarity of some faith communities and organisations - whether the government likes it or not, for it has asked for this kind of critique after all. An ingratiating response, such as we have noted in the case of church organisations remaining silent in the face of legal changes regarding abortion, is neither helpful (nor is it moral) to the government nor to the church as it attempts to fulfil its role of bringing life in all its fullness to all. There is a constant need for surveillance of government policymaking through exhortation, admonition, encouragement and even condemnation at times. This will allow the church to demonstrate its prophetic and visionary credentials, as well as its passion for justice, which are part of its biblical and historic tradition.

The question is also raised whether or not Christianity is a foreign religion and therefore, does it have any place in the new South Africa? While Christianity, as well as Judaism, Islam and other faiths, was brought to South Africa from the West and was marketed as superior to African Traditional Religions (ATRs), it is difficult to categorise it simply as a western faith. Keteyi (1998:34) claims that '[t]here are communities that have already been living Christianity within their cultures for a long time'. Yet, many black people find Christianity a less authentic experience than that which they experience within their traditional faiths. Moreso, while mainline churches still reflect a 
predominantly western lifestyle, with occasional concessions to indigenisation eg. in liturgy, art and ecclesiastical dress, they have been substantially unable to transform themselves, often with two sections existing within one church. This is evidenced in, for example, a black and white church sharing the same name and system of church polity but with differing stipend structures, pension fund arrangements, access to leadership positions and quite different patterns of worship. And all the while, the white section dominates, controls and disparages the 'other' black section as a result of racism, the contemporary evil which dares not speak its name, publicly at least. This poses a question regarding the authenticity of talking about Christianity as a religion without translating the concept into the church as a relevant live force in the community through the rejection of Christianity as a philosophical concept yet, embracing, identifying and participating in the experience of Christianity as a lived faith. Therefore, we would ask what is distinctive about what the church provides? One distinctive mark is that its contribution has often been made on the basis of voluntary commitment which is sometimes lacking in the present 'secularised' context.

Yet, considering that African Initiated Churches (AICs) and black churches have a distinctive African lifestyle, albeit with elements of western ecclesiology, they have become an integral part of African church life - a wonderful combination of order, spontaneity and dignity though it might not always appear so to an outside observer. In fact, they are exhibiting the possibility of becoming new African traditional religions without supplanting their namesakes for they are truly products of Africa though sometimes even they are critical of some of the beliefs and practices of ATR. This may well be because 'they were reverting to traditional ways in which religion and social or political life were one reality' (Keteyi 1998:36). However, it also has to be noted that there is a strong view that the AICs have provided the 'kiss of death' (Maluleke 1998:122) to the ATRs in terms of having supplanted their role in religious society and have consequently led to their 'dismissal' as relevant religious expressions of faith. It is also interesting to note that some AICs claim to have 'kept alive a deep tradition that had sustained people at the local level in a way that organised churches could not do' (James 1999:72) during the years of struggle - a claim which many would not recognise as these very churches have not been treated seriously although Mosala (1996:50) has asserted that they 'provided the impetus and the leadership of this cultural form of resistance and struggle which the Ethiopian type of AIC was to represent'.

Nonetheless, it is a truism that most Africans have never made a complete break with the faith of their forefathers. Maluleke (1998:123) 
would claim that ATRs 'exist inside and outside Christianity, inside and outside Islam - and, in the process, they are radically altering the faces of both Islam and Christianity'. However we must also note that ATRs have an independent existence. It is also true that many Africans have integrated their traditional religion into their Christian faith, even if not explicitly where it exists beneath a veneer of Christianity. This may be because they enable people to express their identity more authentically and, consequently, their feelings of disempowerment. What is sad is the many who for various reasons feel they have to suppress their traditional faith even when it does not explicitly contradict their Christian faith (Theron 1996). Therefore, there is a clear need for the rehabilitation of ATRs so they can take their rightful place in the company of other faiths. They are 'respectable religions [which] merit our respect as much as any other type of religion' (Ter Haar, Moyo \& Nondo 1992:27). In this sense, therefore, they cannot simply be considered as preparatio evangelica (Mbiti).

However, it is necessary to express a word of caution because there is a tendency among us to try to reconstruct the past in the present as if the past reflected an idyllic period historically and culturally. It is important to realise that culture is not static but dynamic. Any call for a return to a particular cultural milieu manifests a specific need to be met and addressed rather than a call to a return to an idyllic past. Therefore there is need for continuity in life vis $a$ vis rapid change such as might emerge from a positive evaluation of traditional practices in terms of continuity v. change, continuity v. suspicion, social cohesion v. individual uniqueness and homogeneity v. pluralism. Constitutional democracy and human rights challenge African communities on these critical value judgments. The challenge is to balance these to offer reassurance, and provide security in a period of fluid social change.

It is a fact that many Africans have rejected their traditional culture. Many now live between two worlds. This attitude was epitomised among the vaTsonga by chief Muhlaba who referred to himself as the 'tree between two fields' (Maluleke 1995:90). This meant 'that for him to be converted ...meant a new and dual existence' (:94) which indicated 'the painful and tense process of being situated at the border between "two worlds"'. This led him to the response of 'religious tolerance' (:94) whereby he neither forced any of his people to adopt Christianity nor did he force those who had become Christians to follow traditional customs which they could no longer in good conscience, and faith, follow (:95). But this tolerance also allowed a fluidity and flexibility in matters of faith expression which might provide us with a dialectical methodology with which to function in contemporary society. 
Although Muhlaba was reacting to mission Christianity in another era, he was pointing to a reality that still needs to be taken account of. Keteyi (1998:22) argued that 'iin order for the church to be truly South African, it needs to be a church in which the many different peoples of South Africa in their cultures and races feel at home in the confident knowledge of who they are'. Questions are bound to arise concerning whether or not traditional chiefs should occupy a position of neutrality politically or religiously. It needs to be asked whether or not this possible or even desirable? If they adopt too rigid and committed positions this might result in them being marginalised in their own communities. Can they be as tolerant as Chief Muhlaba?

This points to another dynamic of the South African situation which impacts upon the area of moral regeneration and social transformation. The Constitution recognises traditional leadership and its institutions as authentic components of the new dispensation. There will obviously be tensions as a result of the revival of traditional leadership roles. Chief Mhulaba exemplified these tensions which raises the question how can traditional leaders remain custodians of tradition and promote them as well as working within the context of Christianity and other faiths? Perhaps, following Muhlaba, they need to debunk the idea of Christian faith being an either/or and rather a both/and 'non-aligned' existence (Maluleke 1995:2009).

The role of the church in our situation has to be many-faceted:-

- to facilitate the dialogue between Christian theology and the ATRs through the agencies of Black and African theology. The approach adopted should be that of hospitality to one another's views in the sense of listening in depth to and accepting the ethos or spirit which lies behind the spoken words in order that the dialogue may take place on the basis of what is heard, felt and experienced rather than assumed or pre-judged.

- to emphasise the social role of religion as a stimulus to prophetic words and actions. This may be a good starting point in relating to other faith communities on the basis of parity. The gains of interfaith dialogue through common membership of political and other organisations during the years of struggle against apartheid should not be lost

- to focus on the need for healing in the sense of creating a new understanding of humanity and of developing a sense of self worth and creativity among its people. This will involve mutual acceptance as well as dealing with a people's memory, forgiveness and creating a 
sense of belonging. Such an emphasis on affirmative action will be truly transformative.

- to develop programmes of action along with NGOs and government through reflection on experiences and adopting insights gained eg. the HIV/AIDS pandemic as all communities are suffering its effects.

- to consider seriously the Constitution and Bill of Rights as sources of humanitarian values which transcend both religious and secular bias and offer a valid spiritual dimension to 'undergirding the common good' (Dandala 1999:56).

- to create communities in which the reality and spirit (ethos) of community can be reincarnated which the church can no longer effectively achieve this on its own. The Church has a great deal to offer in terms of providing a place where the celebration of human community occurs. It can demonstrate the love of God for people as a basis for the mutual care and concern for others.

- to engage in dialogue with partners concerning the ethics of the institutions of government eg. education, health, military, financial bodies. The mission churches have a proud record in the particular areas of education and health, especially in the area of 'character formation'. They still have much in their experience to contribute to the development of a new national character or ethos.

- to empower individuals in communities to discover gifts and skills and take up positions in the community which will enable the transformation of society. This will necessarily involve the promotion of culture positively as a value. This will encourage pride in one's heritage and prepare for a future with all its attendant joys and problems. For instance, using the courage demonstrated by national leaders in the years of struggle in the cause of liberation as a source of teaching.

- to evaluate the potential of dual consciousness cf. dual nationality, by sharing a dual identity as a Christian and African, as a positive factor in forming an African identity through expressing the 'commonality of the people' (Dandala 1999:55).

- to deal equitably and responsibly with the land issue. Historically, many churches possess land which is no longer used or has been lost to individuals who have appropriated it over the years through disuse or carelessness on the church's part. The church must exercise its memory concerning the origin of such lands and take appropriate steps to redress past errors and insensitivities. Its strong biblically based commitment to stewardship in various senses should alert it to its 
ecological responsibilities in terms of the integrity of creation. Sadly, the church has much to repent of here. Yet, there is so much potential for community development through land reform and the church can play a significant 'healing role in the transformation of the country' (Mayende 1997:40).

- to instil hope as a relevant value in members of society. Vast numbers of South Africans seem to have lost hope since the euphoria of 1994. In the face of rising crime levels, abuse (of various kinds) and violence, the rapid advance of the HIV/AIDS pandemic, endemic corruption throughout society and continued grinding poverty which has resulted in low national morale with many who can afford to do so leaving the country searching for a brighter future, the Christian church has a vital role to play in the nurturing of the value of hope. Commenting on 1Peter 3:15, Goba (1997:69) states:

This is not a question of expediency but a call for a critical examination of our moral foundations. I trust we will begin to make the right choices which lead to the creation of a just society which cares for the marginalized, the disabled, the poor, women and children, and become a truly rainbow nation of God.

The fact that we live in a multi-faith context is not going to change. Within such a situation a democracy requires 'religious people who are responsible to transcendent authority. The need always remains for critical distance within the relationship, to enable religious bodies to stand aside in order to be able to speak freely and with a courage without abstaining from taking part in the formation of the value system of society' (James 1999:72).

In sum, we may agree with Theron (1996:10) that '[t]he church has the calling and task to create communities in which ... community can be recaptured' although the church cannot work alone in this'. What is necessary is dialogue and hospitality between faith communities and with all sectors of leadership in order that insights into the nature of ultimate concern (Tillich) or the supreme being and their practical implications such as accountability and moral authority might be shared and better understood and enacted for the good of society as a whole.

\section{Consulted literature}

Bax D 1983 The Bible and Apartheid 2 in De Gruchy and Villa-Vicencio (ed.):112-143.

Cochrane J 1987. Servants of Power: The role of the English-speaking churches in South Africa, $1903-$ 1930. Johannesburg:Ravan.

Cochrane J (ed.) 1999. Religion in Public Life. Cape Town: RICSA.

Dandala M 1999. A call to harness the spirit of the nation in Cochrane J (ed.):53-57.

De Gruchy J \& Villa-Vicencio C (ed.) 1983. Apartheid is a heresy. Cape Town: David Philip.

De Gruchy S (ed.) 1999. Changing Frontiers: The mission story of the UCCSA. Gaborone: Pula. 
Dwane S 1989. God, Religion and Culture: the idea of revelation and its consequences. Lovedale: Lovedale Press.

Goba B 1988. An agenda for Black Theology: hermeneutics for social change. Johannesburg:

Skotaville.

Goba B 1997 in Guma \& Milton (ed.):65-71

Guma M \& Milton AL (ed.) 1997. An African Challenge to the Church in the $21^{\text {st }}$ Century. Johannesburg: SACC.

James W 1999. Faith communities, NGOs and government: First international symposium round table discussion in Cochrane (ed.):71-74.

Keteyi X 1998. Inculturation as a strategy for liberation. Pietermaritzburg: Cluster.

Maluleke TS 1995. 'A morula tree between two fields: The commentary of selected Tsonga writers on Mission Christianity. D.Th thesis. Pretoria: UNISA.

Maluleke TS 1998. African Traditional religions in Christian mission and Christian scholarship: Reopening a debate that never started.. Religion and Theology 5 (no.2):121-137.

Mayende PG 1997 in Guma \& Milton (ed.):32-41.

MkhatshwaS 1999. Assigning responsibility: Response to Jose Chipenda in Cochrane (ed.)67-68.

Mosala IJ 1996. Race, class and gender as hermeneutical factors in the African Independent Churches' appropriation of the Bible. Semeia 73:43-59.

Mulago V 1991. Traditional African Religion and Christianity in Olupona (ed.):119-134.

Odendaal A 1984. Vukani bantu! The beginnings of black protest politics in South Africa. Cape Town: David Philip.

Olupona JK 1991. African Traditional Religions and Contemporary Society. New York: Paragon House.

Omar R 1999. Does public policy need religion? in Cochrane J (ed.):26-29.

Seoka J 1997 in Guma \& Milton (ed.):1-11.

Ter Haar G, Moyo A \& Nondo SJ 1992. African traditional religions in religious education: A resource book with special reference to Zimbabwe. Utrecht: Utrecht University.

Theron PF 1996. African traditional cultures and the church. Pretoria: IMER.

Van der Water D \& de Gruchy S 1999 Submission to the Truth and Reconciliation Commission of South Africa, October 1997in de Gruchy S (ed.) :231- 253

Villa-Vicencio C 1988. Trapped in Apartheid: A socio-theological history of the English-speaking churches. Cape Town: David Philip.

Walshe P 1995. Prophetic Christianity and the Liberation Movement in South Africa.. Pietermaritzburg:Cluster. 